\title{
Penentuan Indeks Seleksi Toleransi Kekeringan Galur Dihaploid Padi Sawah Tadah Hujan pada Fase Perkecambahan
}

\author{
Determination of Drought Tolerance Selection Index in \\ Doubled Haploid Lines of Rainfed Rice at Germination Stage
}

\author{
Miftahur Rizqi Akbar' ${ }^{1}$, Bambang Sapta Purwoko ${ }^{2 *}$, Iswari Saraswati Dewi ${ }^{3}$, dan Willy Bayuardi Suwarno ${ }^{2}$ \\ ${ }^{1}$ Program Studi Pemuliaan dan Bioteknologi Tanaman, Sekolah Pascasarjana, Institut Pertanian Bogor \\ ${ }^{2}$ Departemen Agronomi dan Hortikultura, Fakultas Pertanian, Institut Pertanian Bogor \\ (Bogor Agricultural University), Jl. Meranti, Kampus IPB Darmaga, Bogor 16680, Indonesia \\ ${ }^{3}$ Balai Besar Bioteknologi dan Sumber Daya Genetik Pertanian \\ Jl. Tentara Pelajar No. 3A, Cimanggu, Bogor, Indonesia
}

Diterima 24 Januari 2018/Disetujui 28 Juni 2018

\begin{abstract}
Rainfed rice tolerant to drought and high yielding would be an alternative to rainfed lowland areas prone to drought stress. Selection in the early phase of plant growth will accelerate the effort to obtain rainfed varieties. The objective of this experiment was to identify characters that significantly affect the selection of drought tolerance using PEG 6000 concentration of $25 \%$ in the germination phase. The experiment was conducted in greenhouse of ICABIOGRAD, Bogor, using a factorial randomized complete block design with three replications. The first factor was 32 rice genotypes while the second factor was 2 levels of PEG 6000, i.e., concentrations of 0 and 25\%. The results showed that the correlation analysis and principal component analysis obtain the important characters namely the germination percentage, seminal root length, and the dry weight of seminal roots. Based on discriminant analysis, the index matching value of $96.77 \%$ was suitable to distinguish tolerant and sensitive genotypes using PEG 6000 concentration of $25 \%$ in the germination phase.
\end{abstract}

Keywords: germination percentage, seminal root length, root dry weight

\section{ABSTRAK}

Padi sawah tadah hujan yang toleran kekeringan dan berdaya hasil tinggi dapat menjadi alternatif pada lahan tadah hujan yang rentan cekaman kekeringan. Seleksi pada fase awal pertumbuhan tanaman padi akan mempercepat upaya perakitan varietas padi sawah tadah hujan. Percobaan ini bertujuan untuk mengidentifikasi karakter-karakter yang berpengaruh signifikan pada seleksi toleransi kekeringan menggunakan PEG 6000 konsentrasi 25\% pada fase perkecambahan. Percobaan dilakukan di rumah kaca BB Biogen Cimanggu Bogor, menggunakan rancangan acak kelompok (RAK) 2 faktor dengan 3 ulangan. Faktor pertama adalah 32 genotipe padi sedangkan faktor kedua adalah 2 taraf PEG 6000, yaitu konsentrasi 0 dan 25\%. Hasil pengamatan menunjukkan bahwa analisis korelasi dan komponen utama mendapatkan karakter-karakter penting yaitu persentase perkecambahan, panjang akar seminal, dan bobot kering akar seminal dapat digunakan dalam seleksi genotipe toleran kekeringan. Berdasarkan analisis diskriminan didapatkan nilai kesesuaian persamaan sebesar 96.77\% untuk membedakan genotipe toleran dan sensitif kekeringan pada fase perkecambahan pada konsentrasi $25 \%$ PEG 6000.

Kata kunci: bobot kering akar, panjang akar seminal, persentase perkecambahan

\section{PENDAHULUAN}

Padi merupakan salah satu makanan pokok yang dikonsumsi lebih dari 3 milyar penduduk dunia untuk pemenuhan kebutuhan kalori 50\% hingga 80\% dengan konsumsi terbesar mayoritas berada di Asia (Khush, 2005).

\footnotetext{
* Penulis untuk korespondensi. e-mail: bspurwoko@apps.ipb. ac.id
}

Penduduk dunia diperkirakan akan mencapai 8 milyar pada tahun 2030 sehingga menuntut upaya peningkatan produksi pangan (Villa et al., 2012). Kondisi iklim yang selalu berubah-ubah menjadi permasalahan dalam budidaya pertanian. Kekeringan dapat menurunkan produktivitas secara drastis (Ahadiyat et al., 2014; Maisura et al., 2014). Kekeringan berdampak pada hampir 23 juta hektar padi sawah tadah hujan di dunia (Serraj et al., 2011).

Indonesia memiliki potensi luas sawah tadah hujan sebesar 3.29 juta hektar dengan rata-rata produktivitas 
sebesar 2.5 ton $\mathrm{ha}^{-1}$ (Pirngadi dan Makarim, 2006). Kekeringan menjadi faktor utama yang menyebabkan rendahnya produktivitas padi sawah tadah hujan (Fukai et al., 2009). Perakitan varietas padi sawah tadah hujan toleran kekeringan dan memiliki hasil tinggi merupakan solusi untuk mengatasi kendala dalam peningkatan produktivitas padi sawah tadah hujan (Foley et al., 2011). Pemanfaatan teknik kultur antera dapat mempercepat proses untuk mendapatkan galur-galur murni yang secara konvensional memerlukan waktu 6-8 generasi. Polen pada antera yang bersifat haploid dapat mengganda secara spontan menjadi dihaploid pada saat antera dikulturkan, yang setara dengan galur murni (Dewi dan Purwoko, 2012)..

Salah satu tantangan yang membuat upaya pemuliaan padi toleran kekeringan berjalan lambat adalah belum adanya teknik penapisan yang mampu secara efektif melakukan seleksi galur yang toleran dan galur sensitif (Kamoshita et al., 2008). Penggunaan teknik penapisan yang cepat dan akurat pada fase awal pertumbuhan untuk memperoleh galur-galur yang toleran kekeringan sangat penting dalam pemuliaan tanaman (Boopathi et al., 2013). Penggunaan polyethylene glycol (PEG) 6000 dengan konsentrasi tertentu saat fase perkecambahan dapat dijadikan sebagai alternatif untuk melakukan seleksi secara dini. Cekaman osmotik yang disebabkan oleh PEG 6000 dapat mestimulasi kondisi kekeringan yang ada di lapangan (Mirbahar et al., 2013). Pada kondisi kapasitas lapang, tanah mempunyai potensial osmotik -0.33 Bar sedangkan pada kondisi titik kelembapan kritis mencapai potensial osmotik -15 Bar. Berbagai penelitian melaporkan bahwa penggunaan PEG 6000 dengan konsentrasi 20-25\% setara dengan -6.7 sampai -9.9 Bar mampu membedakan genotipe padi yang toleran maupun peka toleran cekaman kekeringan (Meutia et al., 2010; Afa et al., 2012; Widyastuti et al., 2016). Karakter seleksi pada fase perkecambahan seperti akar yang panjang memiliki korelasi yang positif dengan hasil di lapangan pada kondisi cekaman kekeringan (Abdolshahi et al., 2015). Galur-galur yang memiliki pertumbuhan akar yang baik pada fase perkecambahan akan dapat beradaptasi dengan baik saat terjadi kekeringan pada awal pertumbuhan. Seleksi yang dilakukan pada fase perkecambahan akan memberikan gambaran galur-galur yang toleran dan galur yang sensitif, sehingga dapat melakukan seleksi genotipe secara cepat dan dalam jumlah yang besar. Tujuan percobaan ini adalah mengidentifikasi karakter-karakter yang berpengaruh signifikan pada seleksi toleransi kekeringan menggunakan PEG 6000 konsentrasi 25\% pada fase perkecambahan.

\section{BAHAN DAN METODE}

Percobaan dilakukan pada bulan November sampai Desember 2016 di BB Biogen, Bogor. Materi genetik yang digunakan adalah 28 galur dihaploid hasil kultur antera dan 3 varietas pembanding yaitu Salumpikit (toleran), Inpari 18, dan Ciherang.

Rancangan percobaan yang digunakan adalah faktorial dengan rancangan acak kelompok (RAK). Faktor pertama adalah cekaman kekeringan yang terdiri atas 2 taraf, yaitu kontrol (konsentrasi 0\% larutan PEG 6000) dan konsentrasi 25\% larutan PEG 6000 setara dengan -9.9 bar (Afa et al., 2012). Faktor kedua adalah 28 galur dihaploid padi sawah tadah hujan dan varietas pembanding Salumpikit (toleran), Inpari 18, dan Ciherang. Percobaan diulang sebanyak tiga kali sehingga terdapat 93 satuan percobaan. Satuan percobaan ialah satu cawan petri yang berisi 20 kecambah padi.

Benih dari masing-masing genotipe padi dikecambahkan selama 1-2 hari hingga muncul radikula ( $\pm 2 \mathrm{~mm}$ ) dalam cawan petri yang berisi $10 \mathrm{~mL}$ aquades. Kecambah diseleksi hingga menyisakan 20 kecambah tiap cawan petri. Perlakuan yang diberikan pada masing-masing genotipe yaitu larutan PEG 6000 konsentrasi 25\% dan aquades sebagai kontrol dengan volume $10 \mathrm{~mL}$ tiap cawan petri. Pengamatan dilakukan pada hari ke-7. Karakter yang diamati adalah persentase perkecambahan (jumlah benih yang berkecambah normal/total benih yang dikecambahkan) x 100\%), panjang akar seminal (PAS), panjang tunas (PT), panjang kecambah (PAS + PT), bobot kering akar seminal, dan bobot kering tunas.

Analisis yang dilakukan yaitu analisis ragam sesuai rancangan percobaan yang digunakan. Seleksi awal untuk mencari karakter penting untuk seleksi pada fase perkecambahan dilakukan dengan melihat karakter yang memiliki nilai kuadrat tengah genotipe $(G)$, lingkungan (E), dan interaksi G x E yang nyata. Karakter-karakter tersebut selanjutnya akan dilakukan analisis korelasi Pearson untuk melihat keeratan hubungan antar karakter tersebut. Analisis komponen utama (AKU) berfungsi untuk mengidentifikasi karakter yang berkontribusi besar terhadap keragaman (Golmoghani et al., 2011).

Indeks sensitivitas cekaman kekeringan (ISK) (Fischer \& Maurer, 1978) dihitung dengan rumus : ISK $=(1-\mathrm{Yc} / \mathrm{Yo}) /(1-\mathrm{Xc} / \mathrm{Xo})$, dimana $\mathrm{Yc}=$ rata-rata genotipe tertentu kondisi cekaman kekeringan, Yo = rata-rata suatu genotipe kondisi optimum, $\mathrm{Xc}=$ rata-rata dari seluruh genotipe kondisi cekaman kekeringan, dan Xo = rata-rata dari seluruh genotipe kondisi optimum. Kriteria untuk menentukan tingkat toleransi terhadap cekaman kekeringan adalah jika nilai ISK $\leq 0.5$ maka genotipe tersebut toleran, jika $0.5<\mathrm{ISK} \leq 1.0$ maka genotipe tersebut agak toleran, dan jika ISK $>1.0$ maka genotipe tersebut sensitif (Widyastuti et al., 2016). Nilai ISK dijadikan dasar untuk menentukan pengelompokan sifat toleransi kekeringan dari genotipe yang diuji.

Pengelompokan genotipe kategori toleran dan kategori sensitif berdasarkan nilai indeks sensitivitas kekeringan. Genotipe kategori toleran sebagai kelompok pertama dan genotipe kategori sensitif sebagai kelompok kedua. Karakter yang akan dilakukan analisis diskrimian terlebih dahulu dilakukan standarisasi dengan rumus $\mathrm{Z}_{\mathrm{ij}}=\left(\mathrm{X}_{\mathrm{ij}}-\mathrm{X}_{\mathrm{i}}\right) /$ $S_{i}$, dimana $\mathrm{Z}_{\mathrm{ij}}$ adalah nilai dari standarisasi karakter dari masing-masing genotipe, $\mathrm{X}_{\mathrm{ij}}$ adalah data dari setiap karakter masing-masing genotipe, dan $S_{i}$ adalah standar deviasi dari karakter tersebut. Software yang digunakan untuk analisis ragam, korelasi, komponen utama, dan analisis diskriminan adalah Microsoft Excel 2010 dan STAR IRRI. 


\section{HASIL DAN PEMBAHASAN}

\section{Kondisi Perkecambahan pada Cekaman Kekeringan}

Genotipe-genotipe yang diberi perlakuan PEG 6000 konsentrasi $25 \%$ mengalami penurunan pada karakterkarakter yang diamati jika dibandingkan dengan kontrol (Tabel 1). Pemberian PEG 6000 pada konsentrasi 25\% akan menurunkan potensial air pada media, sehingga tanaman tidak mampu menyerap air pada media. Kumar et al., (2014); Lum et al., (2014); dan Basu et al. (2010) menyatakan bahwa salah satu bentuk mekanisme tanaman yang toleran kekeringan akan menurunkan potensial air dalam tanaman dengan cara menghasilkan senyawa prolin atau poliamin.

Hasil analisis ragam menunjukkan bahwa perlakuan genotipe (G) (data tidak ditampilkan), perlakuan PEG (E) (data tidak ditampilkan), dan interaksi antara genotipe dan perlakuan PEG pada konsentrasi berbeda berpengaruh nyata terhadap karakter persentase perkecambahan, panjang akar seminal, panjang kecambah, bobot kering akar seminal, dan bobot kering tunas (Tabel 1). Perlakuan G dan perlakuan $\mathrm{E}$ berpengaruh nyata pada panjang tunas, akan tetapi memiliki interaksi G x E yang tidak nyata. Perlakuan $\mathrm{G}$ yang berpengaruh nyata menggambarkan adanya perbedaan respon karakter pengamatan yang ditimbulkan karena perlakuan genotipe. Perlakuan E yang berpengaruh nyata menggambarkan adanya perbedaan respon karakter pengamatan yang ditimbulkan karena perlakuan lingkungan yang berbeda. Interaksi G x E yang nyata artinya terdapat perubahan respon yang ditunjukkan oleh suatu genotipe pada lingkungan yang berbeda.
Interaksi $\mathrm{G}$ x E sangat penting dalam proses perakitan genotipe yang toleran terhadap kondisi cekaman. Tanaman yang memiliki daya adaptasi yang baik (toleran) akan mampu tumbuh dan berproduksi pada lingkungan ekstrim atau tercekam kekeringan meskipun mengalami penurunan produksi (Sikuku et al., 2010). Karakter-karakter yang memiliki interaksi $\mathrm{G}$ x $\mathrm{E}$ yang nyata dapat digunakan sebagai dasar untuk melakukan seleksi. Interaksi yang nyata menunjukkan bahwa karakter tersebut dapat memberikan respon berbeda pada kondisi linkungan yang berbeda (Eeuwijk et al., 2016). Mekanisme adaptasi antar genotipe terhadap cekaman kekeringan menunjukkan respon karakter yang berbeda-beda pada lingkungan yang berbeda, sehingga karakter yang dapat menunjukkan adanya perbedaan pada setiap lingkungan sangat penting.

\section{Analisis Korelasi}

Analisis korelasi dilakukan untuk melihat keeratan hubungan antar karakter yang diamati. Analisis korelasi dilaporkan oleh Seyoum et al. (2012); Vaisi \& Golpavar (2013) yang bertujuan untuk mendapatkan kriteria seleksi dalam seleksi simultan. Hasil analisis korelasi Pearson (Tabel 2) menunjukkan bahwa karakter panjang akar seminal memiliki korelasi positif dan tinggi dengan karakter panjang kecambah, bobot kering akar seminal, dan bobot kering tunas. Karakter-karakter yang memiliki korelasi yang positif dan kuat dapat dijadikan acuan untuk melakukan analisis komponen utama (Afa et al., 2013; Widyastuti et al., 2016). Karakter-karakter yang berkorelasi positif dapat digunakan dalam proses seleksi untuk pemilihan karakter

Tabel 1. Rata-rata dan analisis ragam karakter perkecambahan 31 genotipe padi sawah tadah hujan

\begin{tabular}{|c|c|c|c|c|}
\hline \multirow{2}{*}{ Karakter pengamatan } & \multicolumn{2}{|c|}{ Rata-rata $\pm \mathrm{SD}$} & \multirow{2}{*}{$\mathrm{G} \times \mathrm{E}$} & \multirow{2}{*}{$\begin{array}{l}\text { KK } \\
(\%)\end{array}$} \\
\hline & Kontrol & $25 \%$ PEG 6000 & & \\
\hline Persentase perkecambahan (\%) & $99.6 \pm 1.00$ & $67.0 \pm 16.33$ & $* *$ & 17.07 \\
\hline Panjang akar seminal $(\mathrm{cm})$ & $4.5 \pm 0.57$ & $1.2 \pm 0.57$ & $* *$ & 19.38 \\
\hline Panjang tunas $(\mathrm{cm})$ & $6.3 \pm 0.48$ & $0.5 \pm 0.17$ & tn & 15.12 \\
\hline Panjang kecambah $(\mathrm{cm})$ & $10.8 \pm 0.96$ & $1.7 \pm 0.72$ & $* *$ & 12.46 \\
\hline Bobot kering akar seminal (g) & $3.4 \pm 0.40$ & $0.5 \pm 0.25$ & $* *$ & 17.88 \\
\hline Bobot kering tunas $(\mathrm{g})$ & $3.3 \pm 0.43$ & $0.5 \pm 0.21$ & $* *$ & 19.10 \\
\hline
\end{tabular}

Keterangan: *berbeda nyata pada taraf $5 \%$, **berbeda nyata pada taraf $1 \%$, tn tidak berbeda nyata

Tabel 2. Koefisien korelasi karakter-karakter fase perkecambahan pada kondisi cekaman PEG 6000 konsentrasi 25\%

\begin{tabular}{|c|c|c|c|c|}
\hline & $\mathrm{PP}$ & PAS & PK & BKAS \\
\hline PAS & $0.77 * *$ & & & \\
\hline PK & $0.78 * *$ & $0.99 * *$ & & \\
\hline BKAS & $0.71 * *$ & $0.92 * *$ & $0.94 * *$ & \\
\hline BKT & $0.62 * *$ & $0.83 * *$ & $0.86^{* *}$ & $0.90 * *$ \\
\hline
\end{tabular}

Keterangan: $\mathrm{PP}=$ persentase kecambah, $\mathrm{PAS}=$ panjang akar seminal, $\mathrm{PK}=$ panjang kecambah, BKAS = bobot kering akar seminal, BKT $=$ bobot kering tunas, $*$ berbeda nyata pada taraf $5 \%, * *$ berbeda nyata pada taraf $1 \%$ 
yang berpengaruh secara signifikan untuk pemilihan karakter seleksi toleransi kekeringan.

\section{Analisis Komponen Utama}

Analisis analisis komponen utama (AKU) merupakan suatu teknik pengolahan data yang dapat memadatkan set data dari dimensi yang tinggi ke dalam dimensi yang lebih rendah dengan tetap mempertahankan informasi yang terdapat pada data tersebut (Ilin dan Raiko, 2010). Menurut Jolliffe (2002), analisis ini dapat digunakan sebagai suatu persamaan regresi dengan memanfaatkan koefisien variabel pada setiap karakter. Koefisien tersebut merupakan vektor keragaman variabel yang menentukan posisi suatu objek. Penggunaan AKU yang distandarisasi dapat mencegah efek dari multikolinear dalam menentukan bobot karakter pada regresi multivariat (Jolliffe, 2002; Mattjik dan Sumertajaya, 2011) sehingga model yang dihasilkan tidak bersifat overestimate. Oleh sebab itu, penentuan formula regresi menggunakan AKU lebih stabil dibandingkan penentuan regresi secara langsung (Flury \& Riedwly, 1988).

Hasil analisis komponen utama menunjukkan bahwa komponen utama ke-1 memberikan penjelasan keragaman variabel perkecambahan sebesar $87 \%$, sedangkan komponen utama ke-2 sebesar 8\%, dan komponen utama ke-3 sebesar 3\% (Tabel 3). Tingginya kontribusi pada komponen utama ke-1, maka pemilihan karakter-karakter yang berpengaruh penting untuk proses seleksi dapat dipilih pada komponen utama ke-1. Karakter yang dipilih yang memiliki nilai yang besar pada komponen utama ke-1, karakter tersebut adalah panjang akar seminal, panjang kecambah, dan bobot kering akar seminal. Karakter persentase perkecambahan dapat dipilih sebagai karakter seleksi karena karena memiliki nilai yang besar pada komponen utama ke-2. Akumulasi tingkat kontribusi pada komponen utama ke-1 dan komponen utama ke-2 sebesar $87 \%$ dan $95 \%$ sehingga karakter-karakter yang dipilih pada kedua komponen di atas dapat menggambarkan karakter-karakter penting.

\section{Indeks Sensitivitas Kekeringan}

Indeks sensitivitas kekeringan (ISK) merupakan salah satu indeks yang dapat digunakan untuk menilai penurunan pada hasil disebabkan oleh lingkungan suboptimum dibandingkan lingkungan optimum (Fisher dan Maurer, 1978). Nilai ISK yang rendah menunjukkan bahwa genotipe yang diuji pada kondisi sub optimum tidak menunjukkan penurunan yang besar sehingga dapat dikatakan genotipe tersebut toleran.

Karakter-karakter yang digunakan untuk penghitungan nilai ISK dipilih dari hasil analisis korelasi (Tabel 2) dan analisis komponen utama (Tabel 3). Karakter tersebut adalah persentase perkecambahan, panjang akar seminal, dan bobot kering akar seminal. Hasil perhitungan rata-rata ISK pada masing-masing karakter dijadikan sebagai acuan untuk untuk penentuan toleransi kekeringan.

Penentuan toleransi hasil yang didapatkan pada Tabel 4 menunjukkan bahwa 14 genotipe kategori moderat dan 17 genotipe kategori sensitif. Pengelompokan sifat sensitivitas kekeringan terbagi menjadi 2 kelompok besar yaitu moderat dan sensitif. Pembagian dua kelompok sifat toleransi ini nantinya akan dijadikan acuan untuk indeks untuk menduga kelompok genotipe berdasarkan indeks sensitivitas kekeringan berdasarkan karakter yang diamati pada kondisi cekaman PEG 6000 konsentrasi 25\%.

\section{Analisis Diskriminan}

Analisis diskriminan dilakukan untuk mendapatkan persamaan yang dapat digunakan untuk menentukan genotipe yang toleran dan sensitif terhadap cekaman kekeringan. Hasil analisis ragam, analisis korelasi, dan analisis komponen utama didapatkan karakter yaitu persentase perkecambahan, panjang akar seminal, dan bobot kering akar seminal. Analisis diskriminan yang dilakukan didapatkan fungsi persamaan $\mathrm{Y}_{\text {sensitivitas }}=1.0111$ persentase perkecambahan +1.4723 panjang akar seminal -0.7083 bobot kering akar seminal. Nilai kesesuaian dari persamaan di atas sebesar $96.77 \%$, artinya dengan menggunakan persamaan di atas dapat melakukan pendugaan genotipe toleran dan sensitif sebesar $96.77 \%$ dengan melakukan pengamatan pada karakter persentase perkecambahan, panjang akar seminal, dan bobot kering akar seminal pada kondisi cekaman PEG 6000 konsentrasi $25 \%$.

Analisis diskriminan untuk melakukan pendugaan karakter penting dalam melakukan seleksi pada fase perkecambah padi dengan PEG 6000 konsentrasi 25\% dilakukan oleh Widyastuti et al. (2016) mendapatkan

Tabel 3. Analisis komponen utama terhadap karakter perkecambahan

\begin{tabular}{lccc}
\hline Karakter & Komponen utama 1 & Komponen utama 2 & Komponen utama 3 \\
\hline Persentase perkecambahan (\%) & -0.39 & 0.83 & 0.37 \\
Panjang akar seminal (cm) & -0.46 & 0.01 & -0.52 \\
Panjang kecambah (cm) & -0.47 & -0.02 & -0.37 \\
Bobot kering akar seminal (mg) & -0.46 & -0.24 & -0.02 \\
Bobot kering tunas (mg) & -0.43 & -0.49 & 0.65 \\
\hline Nilai eigen & 4.35 & 0.41 & 0.16 \\
Tingkat kontribusi (\%) & 0.87 & 0.08 & 0.03 \\
Akumulasi tingkat kontribusi (\%) & 0.87 & 0.95 & 0.98 \\
\hline
\end{tabular}


karakter-karakter penting untuk penentuan toleransi kekeringan, yaitu panjang akar seminal, vigor benih, panjang kecambah, persentase perkecambahan, dan bobot kering akar seminal. Abdolshahi et al. (2015) menyatakan bahwa hasil analisis diskriminan yang dilakukan dapat digunakan untuk mendapatkan genotipe dengan produksi tinggi di bawah kondisi yang mengalami cekaman kekeringan.

Tabel 4. Indeks sensitivitas kekeringan 31 genotipe padi dihaploid sawah tadah hujan pada perlakuan cekaman kekeringan menggunakan PEG 6000 25\% pada beberapa karakter perkecambahan

\begin{tabular}{|c|c|c|c|c|c|}
\hline Genotipe & $\begin{array}{c}\text { Persentase } \\
\text { perkecambahan }\end{array}$ & $\begin{array}{c}\text { Panjang akar } \\
\text { seminal }\end{array}$ & $\begin{array}{c}\text { Bobot kering akar } \\
\text { seminal }\end{array}$ & Rata-rata indeks & $\begin{array}{l}\text { Sensitivitas } \\
\text { kekeringan }\end{array}$ \\
\hline CG-7-72-1-1 & 0.52 & 0.86 & 0.91 & 0.76 & Moderat \\
\hline CG-7-72-1-2 & 0.61 & 0.98 & 1.00 & 0.86 & Moderat \\
\hline CG-7-72-1-3 & 1.07 & 1.04 & 1.03 & 1.05 & Sensitif \\
\hline CG-7-72-1-4 & 1.07 & 1.09 & 1.03 & 1.06 & Sensitif \\
\hline CG-7-72-1-5 & 0.20 & 0.63 & 0.85 & 0.56 & Moderat \\
\hline CG-7-72-1-6 & 0.87 & 0.84 & 0.97 & 0.90 & Moderat \\
\hline CG-7-72-1-7 & 1.53 & 0.97 & 0.94 & 1.15 & Sensitif \\
\hline CG-8-9-1-2 & 0.42 & 0.80 & 0.89 & 0.70 & Moderat \\
\hline CG-8-9-1-3 & 0.91 & 1.12 & 1.07 & 1.04 & Sensitif \\
\hline CG-8-9-1-4 & 0.57 & 0.96 & 1.02 & 0.85 & Moderat \\
\hline CG-8-9-1-5 & 0.41 & 0.69 & 0.94 & 0.68 & Moderat \\
\hline CG-8-18-1-1 & 1.17 & 1.13 & 1.09 & 1.13 & Sensitif \\
\hline CG-8-18-1-2 & 1.17 & 1.09 & 1.10 & 1.12 & Sensitif \\
\hline CG-8-35-1-2 & 0.71 & 1.12 & 1.06 & 0.97 & Moderat \\
\hline CG-8-92-1-1 & 1.02 & 1.19 & 1.08 & 1.10 & Sensitif \\
\hline CG-8-92-1-2 & 1.07 & 1.07 & 0.99 & 1.04 & Sensitif \\
\hline CG-8-93-1-1 & 0.82 & 0.85 & 1.02 & 0.89 & Moderat \\
\hline CG-8-97-1-1 & 0.71 & 0.99 & 1.00 & 0.90 & Moderat \\
\hline CG-8-97-1-2 & 0.87 & 0.93 & 0.95 & 0.92 & Moderat \\
\hline CG-8-115-1-1 & 1.68 & 1.00 & 1.04 & 1.24 & Sensitif \\
\hline CG-9-2-1-5 & 1.63 & 1.09 & 1.05 & 1.26 & Sensitif \\
\hline CG-9-2-1-6 & 2.18 & 1.16 & 1.08 & 1.47 & Sensitif \\
\hline CG-9-2-1-7 & 0.97 & 1.14 & 1.04 & 1.05 & Sensitif \\
\hline CG-9-5-1-1 & 1.35 & 1.17 & 1.10 & 1.21 & Sensitif \\
\hline CG-9-26-1-1 & 1.94 & 1.14 & 1.03 & 1.37 & Sensitif \\
\hline CG-9-26-1-2 & 1.28 & 1.22 & 1.05 & 1.18 & Sensitif \\
\hline CG-9-26-1-3 & 1.12 & 1.10 & 1.00 & 1.07 & Sensitif \\
\hline CG-9-26-1-4 & 1.89 & 1.18 & 1.11 & 1.39 & Sensitif \\
\hline Ciherang & 0.71 & 0.94 & 0.94 & 0.87 & Moderat \\
\hline Inpari 18 & 0.31 & 0.76 & 0.86 & 0.64 & Moderat \\
\hline Salumpikit & 0.20 & 0.78 & 0.77 & 0.58 & Moderat \\
\hline
\end{tabular}

\section{KESIMPULAN}

Karakter-karakter yang dapat digunakan dalam seleksi dini galur-galur dihaploid padi sawah toleran kekeringan pada fase perkecambahan yaitu persentase perkecambahan, panjang akar seminal, dan bobot kering akar seminal.

\section{UCAPAN TERIMAKASIH}

Ucapan terimakasih disampaikan kepada Kementerian Riset, Teknologi, dan Pendidikan Tinggi, RI yang telah mendanai percobaan ini melalui skema hibah penelitian PMDSU 2016. 


\section{DAFTAR PUSTAKA}

Abdolshahi, R., M. Nazari, A. Safarian, T.S. Sadathossini, M. Salarpour, H. Amiri. 2015. Integrated selection criteria for drought tolerance in wheat (Triticum aestivum L.) breeding programs using discriminant analysis. Field Crops Res. 174:20-29.

Afa, L., B.S. Purwoko, A. Junaedi, O. Haridjaja, I.S. Dewi. 2012. Pendugaan toleransi padi hibrida terhadap kekeringan dengan polyetilen glikol (PEG) 6000. J. Agrivigor 11:292-299.

Afa, L., B.S. Purwoko, A. Junaedi, O. Haridjaja, I.S. Dewi. 2013. Deteksi dini toleransi padi hibrida terhadap kekeringan menggunakan PEG 6000. J. Agron. Indonesia 41:9-15.

Ahadiyat, Y.R, P. Hidayat, U. Susanto. 2014. Drought tolerance, phosphorus efficiency and yield characters of upland rice lines. Emir J. Food Agric. 26:25-34.

Basu, S., A. Roychoudhury, P.P. Saha, D.N. Sengupta. 2010. Comparative analysis of some biochemical responses of three indica rice varieties during polyethylene glycol-mediated water stress exhibits distinct varietal differences. Acta Physiol. Plant. 32:551-563.

Boopathi, N.M., G. Swapnashri, P. Kavitha, S. Sathish, R. Nithya, W. Ratnam, A. Kumar. 2013. Evaluation and bulked segregant analysis of major yield QTL 12.1 intogressed into indigenous elite line for low water availability under water stress. Rice Sci. 20:25-30.

Dewi, I.S., B.S. Purwoko. 2012. Kultur antera untuk percepatan perakitan varietas padi di Indonesia. J. AgroBiogen 8:78-88.

Eeuwijk, F.A.V., D.V. Bustos-Korts, M. Malosetti. 2016. What should students in plant breeding know about the statistical aspects of genotype environment interactions. Crop Sci. 56:2119-2140.

Fischer, R.A., R. Maurer. 1978. Drought resistance in spring wheat cultivars. I. Grain yield response. Aust. J. Agric. Res. 29:897-907.

Foley, J.A., N. Ramankutty, K.A. Braumann, E.S. Cassidy, J.S. Gerber, M. Johnston, N.D. Mueller, C. O'Connell, D.K. Ray, P.C. West, C. Balzer, E.M. Bennett, S.R. Carpenter, J. Hill, C. Monfreda, S. Polasky, J. Rockström, J. Sheehan, S. Siebert, D. Tilman, D.P.M. Zaks. 2011. Solutions for a cultivated planet. Nature 478:337-342.

Fukai, S., J. Basnayake, O. Makara. 2009. Drought resistance characters and variety development for rainfed lowland rice in Southeast Asia. In: R. Serraj,
J. Bennett, B. Hardy (Eds.). Drought Frontiers in Rice: Crop Improvement for Increased Rainfed Production. International Rice Research Institute. Los Banos, PH.

Golmoghani, A., K.A. Hamdollah, Y. Mehrdad, A. Golamreza, G.A. Leila, G. Taregh. 2011. Evaluation of drought tolerance indices and grain yield in wheat genotypes using principal components analysis. Middle-East J. Sci. Res. 8:880-884.

Ilin, A., T. Raiko. 2010. Pratical approaches to principal component analysis in the presence of missing values. J. Mach. Learn. Res. 11:1957-2000.

Jolliffe, I.T. 2002. Principal Component Analysis, Second Edition. Springer-Verlag, Inc., New York, USA.

Kamoshita, A., C. Babu, N.M. Boopathi, S. Fukai. 2008. Phenotypic and genotypic analysis of droughtresistance traits for development of rice cultivars adapted to rainfed environments. Field Crops Res. 109:1-23.

Khush, G.S. 2005. What it will take to feed 5.0 billion rice consumers in 2030. Plant Mol. Biol. 59:1-6.

Kumar, S., S.K. Dwivedi, S.S. Singh, B.P. Bhatt, P. Mehta, R. Elanchezhian, V.P. Singh, O.N. Singh. 2014. Morphophysiological traits associated with reproductive stage drought tolerance of rice (Oryza sativa L.) genotypes under rain-fed condition of eastern Indo-Gangetic Plain. Indian J. Plant Physiol. 19:87-93.

Lum, M.S., M.M. Hanafi, Y.M. Rafii, A.S.N. Akmar. 2014. Effect of drought stress on growth, proline and antioxidant enzyme activities of upland rice. J. Anim. Plant Sci. 24:1487-1493.

Maisura, M.A. Chozin, I. Lubis, A. Junaedinand, H. Ehara. 2014. Some physiological character responses of rice under drought conditions in a paddy system. J. Int. Soc. Southeast Asian Agric. Sci. 20:104-114.

Mattjik, A.A., I.M. Sumertajaya. 2011. Sidik Peubah Ganda dengan Menggunakan SAS. Statistika F-MIPA IPB, Bogor, ID.

Meutia, S.A., A. Anwar, I. Suliansyah. 2010. Uji toleransi beberapa genotipe padi lokal (Oryza sativa L.) Sumatera Barat terhadap cekaman kekeringan. Jerami. 3:71-81.

Mirbahar, A.A., R. Saeed, G.S. Markhand. 2013. Effect of polyethylene glycol-6000 on wheat (Triticum aestivum L.) seed germination. Int. J. Biol. Biotech. 10:401-405. 
Pirngadi, K., A.K. Makarim. 2006. Peningkatan produktivitas padi pada lahan sawah tadah hujan melalui pengelolaan tanaman terpadu. J. Penelitian Pertanian Tanaman Pangan 25:116-123.

Serraj, R., K.L. McNally, I. Slamet-Loedin, A. Kohli, S.M. Haefele, G. Atlin, A. Kumar. 2011. Drought resistance improvement in rice: An integrated genetic and resource management strategy. Plant Prod. Sci. 14:1-14.

Seyoum, M., S. Alamerew, K. Bantte. 2012. Genetic variability, heritability, coefficient and path analysis for yield and yield related traits in upland rice (Oryza sativa L.). J. Plant Sci. 7:13-22.

Sikuku, P.A., G.W. Netondo, D.M. Musyimi, J.C. Onyango. 2010. Effects of water deficit on days to maturity and yield of three NERICA rainfed rice varieties. ARPN J. Agric. Biol. Sci. 5:1-9.

Vaisi, H., A.R. Golpavar. 2013. Determination of the best indirect selection criteria to improve grain yield and seed weight in oat (Avena sativa L.) genotypes. IJFAS. 2:747-750.

Villa, J.E., A. Henry, F. Xie, R. Serraj. 2012. Hybrid rice performance in environments of increasing drought severity. Field Crops Res. 125:14-24.

Widyastuti, Y., B.S. Purwoko, M. Yunus. 2016. Identifikasi toleransi kekeringan tetua padi hibrida pada fase perkecambahan menggunakan polietilen glikol (PEG) 6000. J. Agron. Indonesia 44:235-241. 